\title{
Editorial: Ocean Island Volcanoes: Genesis, Evolution and Impact
}

\author{
Adriano Pimentel ${ }^{1,2,3 *}$, Ricardo S. Ramalho ${ }^{4,5,6,7}$, Laura Becerril ${ }^{8}$, Patricia Larrea ${ }^{9}$ and \\ Richard J. Brown ${ }^{10}$ \\ ${ }^{1}$ Centro de Informação e Vigilância Sismovulcânica dos Açores (CIVISA), Ponta Delgada, Portugal, ${ }^{2}$ Instituto de Investigação \\ em Vulcanologia e Avaliação de Riscos (IVAR), Universidade dos Açores, Ponta Delgada, Portugal, ${ }^{3}$ Centro de Investigação \\ em Biodiversidade e Recursos Genéticos (CIBIO), InBIO Laboratório Associado, Pólo dos Açores, Ponta Delgada, Portugal, \\ ${ }^{4}$ Instituto Dom Luiz (IDL), Faculdade de Ciências, Universidade de Lisboa, Lisbon, Portugal, ${ }^{5}$ Departamento de Geologia, \\ Faculdade de Ciências, Universidade de Lisboa, Lisbon, Portugal, ${ }^{6}$ School of Earth Sciences, University of Bristol, Bristol, \\ United Kingdom, ${ }^{7}$ Lamont-Doherty Earth Observatory at Columbia University, Palisades, NY, United States, ${ }^{8}$ Servicio \\ Nacional de Geología y Minería (SERNAGEOMIN), Santiago, Chile, ${ }^{9}$ Department of Geology and Andean Geothermal Center \\ of Excellence, Facultad de Ciencias Físicas y Matemáticas, Universidad de Chile, Santiago, Chile, ${ }^{10}$ Department of Earth \\ Sciences, Durham University, Durham, United Kingdom
}

Keywords: hotspots, magmatic processes, seamounts, geochronology, tectonic control, flexure models, volcanic hazard

\section{Editorial on the Research Topic}

\section{Ocean Island Volcanoes: Genesis, Evolution and Impact}

Ocean island volcanoes are exceptional geological features that rise from the seafloor. They are small windows in the vast oceans that allow an indirect look into the otherwise inaccessible Earth's interior. The genesis of ocean island volcanoes is intrinsically related to their geodynamic setting and magma-supply rate over time (Menard and Ladd, 1963). However, ocean island magmatism cannot be explained within the framework of plate tectonics without the presence of mantle melting anomalies. How ocean island magmas are generated, evolve, and erupt are key questions for petrology and volcanology. The geological evolution of ocean island volcanoes is governed by multiple internal and external factors. A better knowledge of the interplay between growth and decay processes is crucial for a comprehensive understanding of the evolution of such volcanoes (Ramalho et al., 2013). On account of their typically isolated location and small area, ocean islands are especially vulnerable to geological hazards. Volcanic eruptions, in particular, may have devastating consequences on local communities, but also impact global economy and climate (Wilson et al., 2014). It is therefore crucial to increase our knowledge on these volcanoes to respond to the challenge of forecasting future eruptions and their short- to long-term impacts. This Research Topic covers different subjects related to ocean island volcanoes within the Pacific and Atlantic Oceans.

Haase et al. address the process of melting by mantle plumes, through a comparison of intraplate volcanoes in the Pacific Ocean. The authors compare published compositional and geochronological data from Hawaii, Society, Marquesas and Samoa, finding systematic variations of magma composition with similar-sized melting anomalies, notwithstanding the different temperatures. They show that shield stages last $\sim 1 \mathrm{Ma}$ and there is an overlap of shield and post-shield volcanism for up to $200 \mathrm{ky}$. The study suggests that the evolution of these volcanoes does not strictly follow the Hawaiian model.

Harpp and Geist offer a comparative study of geological, geochemical, and geophysical data to investigate the evolution of the western and eastern Galápagos, concluding that it is conditioned by a change in tectonic setting $\sim 1 \mathrm{Ma}$ ago. The authors suggest that the eastern volcanoes are not an evolved stage of the young western volcanoes, but conversely were emplaced in a near-ridge environment with a lower magma-supply rate. They also suggest western volcanoes were formed by a different constructional mechanism controlled 
by the proximity of the Galápagos Spreading Center 1 to 3 Ma ago.

Continuing in the Galápagos, Schwartz et al. look at the shallow seamounts near the western Galápagos to identify erosional or volcanic terrace-like morphologic features using direct seafloor observations and bathymetrical information. This study confirms that the western archipelago experienced significant subsidence at rates of $0.2-0.4 \mathrm{~m} / \mathrm{ka}$ over the past $1 \mathrm{Ma}$, concluding that all islands in the central archipelago were intermittently connected between 435 and $900 \mathrm{ka}$.

Thordarson and Garcia discuss the origins of the rejuvenated volcanism at Kilauea Point, Kaua'i (Hawai'i) by looking at the products of three well-dated rejuvenated stage eruptions. The authors conclude that the timing of volcanism and the elevation of Kilauea Point relative to sea level are inconsistent with the predictions of the flexural melting model, indicating that decompression melting related to plate flexure cannot be the sole driver for the rejuvenated volcanism.

Lara et al. provide new dating along the Juan Fernández Ridge to test the hypothesis that this volcanic chain constitutes a hotspot track. Newly obtained ${ }^{40} \mathrm{Ar} /{ }^{39} \mathrm{Ar}$ ages range from 8.4 to $0.62 \mathrm{Ma}$ and show an east-west gradation. These results indicate a clear age progression with a mean Nazca plate velocity of $\sim 81 \mathrm{~mm} / \mathrm{yr}$, which is consistent with a hotspot track resulting from the impingement of a mantle plume beneath the Juan Fernández Ridge.

Le Corvec and McGovern investigate how loading of ocean water affects the internal stress of basaltic island volcanoes. Specifically, they run two finite element models, one considering an instantaneous volcanic edifice growth, and a second one with an edifice incrementally built over time. Their results show that eruptions are more likely to occur within incrementally-built edifices, irrespective of the load of a water body, but where the stress signatures of lithospheric flexure are reduced.

Moving to the Atlantic Ocean, Romer et al. investigate the relationship between magmatic and tectonic processes in Faial volcanic system (Azores), through a combined bathymetric, geophysical, geochemical, and isotopic approach. They show that the stress field under Faial has not changed in the last $1 \mathrm{Ma}$, despite a progressive decrease in melt productivity over time. This suggests that the distribution of compositionally similar lavas is tectonically controlled. The youngest mafic and intermediate melts were erupted along rift zones from a

\section{REFERENCES}

Menard, H., and Ladd, H. (1963). "Oceanic islands, seamounts, guyots and atolls," in The Sea, Vol. 3, ed M. N. Hill (New York, NY: Wiley Interscience), 365-385.

Ramalho, R. S., Quartau, R., Trenhaile, A. S., Mitchell, N. C., Woodroffe, C. D., and Ávila, S. P. (2013). Coastal evolution on volcanic oceanic islands: a complex interplay between volcanism, erosion, sedimentation, sea-level change and biogenic production. Earth Sci. Rev. 127, 140-170. doi: 10.1016/j.earscirev.2013.10.007

Wilson, G., Wilson, T. M., Deligne, N. I., and Cole, J. W. (2014). Volcanic hazard impacts to critical infrastructure: a review. J. Volcanol. Geotherm. Res. 286, 148-182. doi: 10.1016/j.jvolgeores.2014.08.030 more enriched source, whilst the older, and more widespread volcanism was originated from a more depleted one.

Jeffery and Gertisser review the occurrence of peralkaline felsic magmatism in Atlantic volcanoes through a review of published geochemical, thermobarometric, and geochronological datasets to identify the primary controls of formation of such magmas. The authors suggest that peralkaline magmas in these islands are generated primarily by extended (up to 95\%), open system fractional crystallization of mantle-derived mafic magmas. They also suggest that the magma generation is likely controlled by the system magma-flux rate.

Finally, Kueppers et al. address the problem of potentially biased volcanic hazard assessments due to incomplete eruption records at ocean island volcanoes. Using a recently discovered mid-distal pumice lapilli fall deposit in the central part of São Miguel (Azores), the authors constrained the eruptive source parameters and wind conditions during the last paroxysmal explosive eruption of Sete Cidades volcano. Critically, the newly obtained parameters allow a more realistic assessment of the potential impact that a future sub-Plinian eruption would have on the island.

This collection of articles offers probe of some of the critical questions and possible answers in our stepwise understanding of ocean island volcanoes, and they highlight the uniqueness and complexity of these geological features. We anticipate this Research Topic to be a valuable reference for future research on ocean island volcanoes and will stimulate thinking on some key problems related to their genesis, growth and hazards.

\section{AUTHOR CONTRIBUTIONS}

All authors listed have made a substantial, direct and intellectual contribution to the work, and approved it for publication.

\section{FUNDING}

RR acknowledges his IF/01641/2015 Investigador FCT contract. PL was supported by Fondos de Instalación Académica - FCFM, Universidad de Chile.

\section{ACKNOWLEDGMENTS}

We thank the chief editor Valerio Acocella for the kind invitation to organize this Research Topic.
Conflict of Interest: The authors declare that the research was conducted in the absence of any commercial or financial relationships that could be construed as a potential conflict of interest.

Copyright (C) 2020 Pimentel, Ramalho, Becerril, Larrea and Brown. This is an openaccess article distributed under the terms of the Creative Commons Attribution License (CC BY). The use, distribution or reproduction in other forums is permitted, provided the original author(s) and the copyright owner(s) are credited and that the original publication in this journal is cited, in accordance with accepted academic practice. No use, distribution or reproduction is permitted which does not comply with these terms. 